\title{
Functional genomics of lung cancer progression reveals mechanism of metastasis suppressor function
}

\author{
Ram Krishna Thakur ${ }^{1 \dagger}$, Vinod Kumar Yadav ${ }^{2 \dagger}$, Akinchan Kumar ${ }^{1 \dagger}$, Richa Basundra ${ }^{1}$, Anirban Kar $^{1}$, Rashi Halder ${ }^{1}$, \\ Ankita Singh ${ }^{1}$, Pankaj Kumar ${ }^{2}$, Aradhita Baral ${ }^{1}$, MJ Mahesh Kumar ${ }^{3}$, Krishnendu Pal $^{4}$, Rajkumar Banerjee ${ }^{4}$, \\ Shantanu Chowdhury ${ }^{1,2^{*}}$
}

From International Conference on Human Genetics and 39th Annual Meeting of the Indian Society of Human Genetics (ISHG) Ahmadabad, India. 23-25 January 2013

The mechanism of action of NME2, a widely accepted metastasis-suppressor gene, is poorly understood. Recently we found that NME2 directly regulates transcription of the $c-M Y C$ proto-oncogene. This prompted a genomewide study to ascertain whether NME2 exerts its anti-metastatic action through transcriptional regulation. Chromatin-immunoprecipitation followed by massively parallel sequencing (ChIPseq) along with transcriptome profiling uncovered a network of genes involved in intercellular contact, focal adhesion and actin assembly under direct transcriptional control of NME2. In line with this, NME2-depleted cells displayed increased focal adhesion points and altered actin stress fiber organization. Our findings demonstrate that NME2 regulates transcription of a key focal adhesion factor vinculin and its localization within adhesion foci. NME2-depleted A549 lung cancer cells showed higher invasiveness in vitro and seeded more metastases in vivo. Consistent with these findings, expression of several NME2-transcriptional target genes related closely to advanced tumor stages with metastatic proclivity, and NME2 levels predicted patient survival.

\footnotetext{
Authors' details

${ }^{1}$ Proteomics and Structural Biology Unit. ${ }^{2}$ G.N.R. Knowledge Centre for Genome Informatics, CSIRInstitute of Genomics and Integrative Biology, Delhi, India. ${ }^{3}$ Animal House, CSIR-Centre for Cellular and Molecular Biology, Uppal Road, Hyderabad, India. ${ }^{4}$ Division of Lipid Science and Technology, CSIR-Indian Institute of Chemical Technology, Hyderabad, India.
}

\footnotetext{
* Correspondence: shantanuc@igib.res.in

† Contributed equally

${ }^{1}$ Proteomics and Structural Biology Unit

Full list of author information is available at the end of the article
}

Published: 21 January 2014

doi:10.1186/1755-8166-7-S1-19

Cite this article as: Thakur et al.: Functional genomics of lung cancer progression reveals mechanism of metastasis suppressor function. Molecular Cytogenetics 2014 7(Suppl 1):19.
Submit your next manuscript to BioMed Central and take full advantage of:

- Convenient online submission

- Thorough peer review

- No space constraints or color figure charges

- Immediate publication on acceptance

- Inclusion in PubMed, CAS, Scopus and Google Scholar

- Research which is freely available for redistribution

Submit your manuscript at www.biomedcentral.com/submit
C Biomed Central 